\title{
Response of lactating dairy cows to high protein distillers grains or 3 other protein supplements
}

\author{
K. A. Christen, ${ }^{* 1}$ D. J. Schingoethe, ${ }^{* 2}$ K. F. Kalscheur, ${ }^{*}$ A. R. Hippen, ${ }^{*}$ K. K. Karges, $†$ and M. L. Gibson† \\ *Dairy Science Department, South Dakota State University, Brookings 57007-0647 \\ †Dakota Gold Research Association, Sioux Falls, SD 57104
}

\begin{abstract}
This study compared high protein dried distillers grains (HPDDG) with soybean meal (SBM), canola meal $(\mathrm{CM})$, and dried distillers grains with solubles (DDGS) as protein supplements in dairy diets. A lactation trial used 12 multiparous cows averaging $78 \mathrm{~d}$ in milk at the start of the experiment in a $4 \times 4$ Latin square design with 28-d periods. Weeks 1 and 2 of each period were used for adjustment and wk 3 and 4 for data collection. Each treatment diet consisted of $55 \%$ forage and one of the 4 protein supplements in a concentrate mix. Total mixed diets averaged $15.3 \%$ crude protein, with $38 \%$ of the protein from one of the 4 protein supplements. Dry matter intake $(24.4 \mathrm{~kg} / \mathrm{d})$ and crude protein intake $(3.57 \mathrm{~kg} / \mathrm{d})$ were similar for all 4 diets. Milk production $(31.8 \mathrm{~kg} / \mathrm{d})$, protein yield $(1.05 \mathrm{~kg} / \mathrm{d})$, fat yield $(1.29$ $\mathrm{kg} / \mathrm{d}$ ), and protein percentage (3.31) were similar for all 4 treatment diets. Milk fat percentage was lower when fed DDGS (3.78) than when fed SBM or HPDDG (4.21), but similar with CM (4.07). Feed efficiency (1.44 $\mathrm{kg}$ of energy-corrected milk/ $\mathrm{kg}$ of dry matter intake) and nitrogen efficiency (0.29) were not affected by diet. Total milk nitrogen and true milk protein were highest when fed the HPDDG diet. Molar proportions of acetate, propionate, and the acetate to propionate ratio in ruminal contents and ruminal ammonia concentrations were similar for all diets. Arterial and venous concentrations of total essential AA tended to be lower when fed CM, reflecting lower concentrations of His, Ile, Leu, and Val when fed the CM diet. Extraction efficiency of AA from blood by the mammary gland indicated that Met was the first limiting AA when fed the SBM diet, whereas Lys was first limiting for the other diets. Phenylalanine was third limiting with all diets. Feeding HPDDG was equally as effective as feeding SBM, CM, and regular distillers grains as a protein supplement for lactating cows.
\end{abstract}

Received September 1, 2009.

Accepted February 2, 2010.

${ }^{1}$ Current address: Vita Plus Corp., Loyal, WI 54446.

${ }^{2}$ Corresponding author: david.schingoethe@sdstate.edu
Key words: distillers grain, high protein distillers grain, canola meal, lactating cow

\section{INTRODUCTION}

Dried distillers grains with solubles (DDGS) is the primary coproduct of ethanol production from corn and other grains. Several studies (e.g., Nichols et al., 1998; Anderson et al., 2006; Kleinschmit et al., 2006) demonstrated that DDGS can effectively replace soybean meal (SBM) as a protein source, but there is less evidence comparing DDGS with other protein supplements. Mulrooney et al. (2009) reported similar milk production when fed DDGS or canola meal (CM) as the protein supplement, although milk yield and protein yield responses and extraction efficiency of AA by the mammary gland (i.e., arteriovenous difference of an AA across the mammary gland relative to arterial concentration of the AA) indicated some benefits of feeding a combination of CM and DDGS rather than only one of them as the protein supplement.

Ethanol plants are attempting to improve the fermentation of corn to ethanol and this is resulting in new products (Robinson et al., 2008). One way this is accomplished is through fractionation of the corn in which the germ and the bran are removed before fermentation. This new product, called high protein dried distiller grains (HPDDG), is higher in CP and lower in fat $(44 \% \mathrm{CP}, 3.4 \%$ fat) than DDGS $(30 \% \mathrm{CP}, 10 \%$ fat) produced through traditional ethanol fermentation processes (Robinson et al., 2008). The HPDDG is a product that is closer in nutrient composition to $\mathrm{CM}$ and SBM. Hubbard et al. (2009) recently reported that feeding HPDDG increased milk production relative to the feeding of an SBM-based diet, but HPDDG has not been compared with CM. The objective of this study was to determine the response in milk production to diets that contained each of SBM, HPDDG, CM, or DDGS as the supplemental protein.

\section{MATERIALS AND METHODS}

All procedures for this study were conducted under approval of the South Dakota State University Animal 
Table 1. Ingredient composition of diets ${ }^{1}$

\begin{tabular}{|c|c|c|c|c|}
\hline Item, $\%$ of DM & $\mathrm{SBM}$ & HPDDG & $\mathrm{CM}$ & DDGS \\
\hline Corn silage & 27.5 & 27.5 & 27.5 & 27.5 \\
\hline Alfalfa hay & 27.5 & 27.5 & 27.5 & 27.5 \\
\hline Corn ground dry & 29.3 & 28.4 & 28.8 & 21.3 \\
\hline DDGS & 0.0 & 0.0 & 0.0 & 21.2 \\
\hline $\mathrm{SBM}, 44 \% \mathrm{CP}$ & 11.1 & 0.0 & 0.0 & 0.0 \\
\hline HPDDG & 0.0 & 12.0 & 0.0 & 0.0 \\
\hline Canola meal & 0.0 & 0.0 & 12.7 & 0.0 \\
\hline $\mathrm{Fat}^{2}$ & 2.0 & 1.8 & 1.2 & 0.0 \\
\hline Dicalcium phosphate & 0.40 & 0.60 & 0.17 & 0.0 \\
\hline Magnesium oxide & 0.07 & 0.08 & 0.05 & 0.07 \\
\hline Limestone & 0.73 & 0.72 & 0.71 & 1.05 \\
\hline Salt & 0.55 & 0.55 & 0.55 & 0.55 \\
\hline Mineral-vitamin $\operatorname{mix}^{3}$ & 0.6 & 0.6 & 0.6 & 0.6 \\
\hline Vitamin A, D, E mix ${ }^{4}$ & 0.2 & 0.2 & 0.2 & 0.2 \\
\hline Vitamin $\mathrm{E}^{5}$ & 0.05 & 0.05 & 0.05 & 0.05 \\
\hline
\end{tabular}

${ }^{1} \mathrm{SBM}=$ soybean meal; HPDDG $=$ high protein dried distillers grains with solubles; $\mathrm{CM}=$ canola meal; DDGS $=$ dried distillers grains with solubles. Dietary treatments consisted of 4 different protein sources (SBM, HPDDG, CM, and DDGS) intended to supply equal amounts of protein (approximately $38 \%$ of the total dietary protein) from the respective supplemental protein sources.

${ }^{2}$ Energy Booster 100 (Milk Specialties Company, Dundee, IL).

${ }^{3}$ Guaranteed analysis: Mg, 10.0\%; Mn, 1.7\%; Zn, 2.6\%; Cu, 4,712 mg/kg; Co, 119 mg/kg; I, 396 mg/kg; Se, 140 $\mathrm{mg} / \mathrm{kg}$; Fe, 4,640 mg/kg; vitamin A, 2,640,000 IU/kg; vitamin D, 528,000 IU/kg; vitamin E, 10,560 IU/kg.

${ }^{4}$ Guaranteed analysis: vitamin A, 5,500,000 IU/kg; vitamin D, 880,000 IU/kg; vitamin E, 2,200 IU/kg.

${ }^{5} 44,000 \mathrm{IU} / \mathrm{kg}$.

Care and Use Committee. Twelve multiparous Holstein cows $(78 \pm 24$ DIM) were used in a replicated $4 \times 4$ Latin square design with 28 -d periods. Weeks 1 and 2 of each period were for adjustment to diets and wk 3 and 4 for data collection. Dietary treatments consisted of 4 different protein sources (SBM, HPDDG, CM, and DDGS) intended to supply equal amounts of protein (approximately $38 \%$ of the total dietary protein) from the respective supplemental protein sources. All diets contained $27.5 \%$ alfalfa hay and $27.5 \%$ corn silage on a DM basis (Table 1). The diets were formulated to be isonitrogenous at $16.0 \% \mathrm{CP}$ and isolipogenic at $4.7 \%$ fat (Table 2). Energy Booster (Milk Specialties Company, Dundee, IL) was added to all except the DDGS diet to maintain approximately equal ether extract concentration in all diets. All other nutrients were formulated to meet or exceed the requirements according to NRC (2001). Cows were housed in a free-stall barn and individually fed diets as a TMR for ad libitum intake once daily (0800 h) using Calan Broadbent feeder doors (American Calan Inc., Northwood, NH). Feed intakes were recorded daily.

Samples of forages, concentrates, SBM, HPDDG, CM, and DDGS were collected for 2 consecutive days at the end of each period and stored at $-20^{\circ} \mathrm{C}$ until analysis. Samples were composited by period and dried at $55^{\circ} \mathrm{C}$ in a Despatch oven (Despatch Oven Co., Minneapolis, MN) for $48 \mathrm{~h}$. Composites were ground through a 4-mm screen in a Wiley mill (Arthur H, Thomas Co., Philadelphia, PA) and then through a 1-mm screen in an ultracentrifuge mill (Brinkman Instruments Co., Westbury NY). Samples were corrected to $100 \%$ DM by drying an aliquot of the composite at $105^{\circ} \mathrm{C}$ for $24 \mathrm{~h}$ (method 930.15; AOAC, 2002). Samples were analyzed for CP (method 990.03; AOAC, 2002), ether extract with petroleum ether (method 930.39; AOAC, 2002), and ash (method 942.05; AOAC, 2002). Neutral detergent fiber was determined with sodium sulfite and

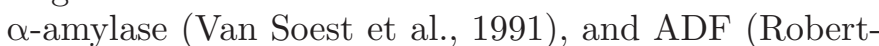
son and Van Soest, 1981) sequentially with an Ankom Fiber Analyzer (Ankom Technology Corp., Fairport, NY). Composition of the TMR was calculated based on analyses and concentrations in the diets of the concentrate mix and the individual forages.

Cows were milked 3 times daily at 0600, 1400, and $2100 \mathrm{~h}$ and yields were recorded. Milk samples were collected for each milking on 2 consecutive days during the last 2 wk of each period. Samples were mixed by gentle inversion and composited by weight corresponding to the respective milking for each cow on sampling day. These samples were sent to Heart of America DHI laboratory (Manhattan, KS) for composition analysis where fat, true protein, and lactose were determined using mid-infrared spectroscopy (Bentley 2000 Infrared Milk Analyzer, Bentley Instruments, Chaska, MN; method 972.16; AOAC, 2002). Concentrations of MUN were determined using chemical methodology based on a modified Berthelot reaction (ChemSpec 150 Analyzer, Bentley Instruments; Chaney and Marbach, 1962), and SCC was determined using a flow cytometer laser 
Table 2. Nutrient composition of $\operatorname{diets}^{1}$

\begin{tabular}{|c|c|c|c|c|}
\hline Item & SBM & HPDDG & $\mathrm{CM}$ & DDGS \\
\hline \multicolumn{5}{|c|}{ Formulated, $\%$ of DM unless noted } \\
\hline $\mathrm{CP}$ & 16.0 & 16.0 & 16.0 & 16.0 \\
\hline $\mathrm{RDP}^{2}$ & 11.1 & 10.2 & 11.0 & 10.1 \\
\hline $\mathrm{RUP}^{2}$ & 4.9 & 5.8 & 5.0 & 5.8 \\
\hline Ether extract & 4.7 & 4.7 & 4.7 & 4.7 \\
\hline $\mathrm{ADF}$ & 19.0 & 19.2 & 20.5 & 19.6 \\
\hline $\mathrm{NDF}$ & 27.3 & 28.0 & 29.4 & 30.3 \\
\hline Forage NDF & 22.9 & 22.9 & 22.9 & 22.9 \\
\hline $\mathrm{NFC}$ & 46.4 & 47.0 & 45.1 & 45.1 \\
\hline $\mathrm{NE}_{\mathrm{L}},{ }^{2} \mathrm{Mcal} / \mathrm{kg}$ & 1.59 & 1.59 & 1.59 & 1.59 \\
\hline $\mathrm{Ca}$ & 0.9 & 0.9 & 0.9 & 0.9 \\
\hline $\mathrm{P}$ & 0.4 & 0.4 & 0.4 & 0.4 \\
\hline \multicolumn{5}{|c|}{ Measured, $\%$ of DM unless noted } \\
\hline $\mathrm{DM}, \%$ & 68.8 & 68.8 & 69.6 & 69.2 \\
\hline $\mathrm{CP}$ & 15.4 & 15.0 & 15.6 & 15.3 \\
\hline Ether extract & 4.7 & 4.6 & 4.5 & 4.1 \\
\hline $\mathrm{ADF}$ & 16.2 & 16.6 & 17.7 & 17.0 \\
\hline $\mathrm{NDF}$ & 27.4 & 31.1 & 28.9 & 31.2 \\
\hline Forage NDF & 22.7 & 22.7 & 22.7 & 22.7 \\
\hline Ash & 6.22 & 6.27 & 6.71 & 6.22 \\
\hline $\mathrm{NFC}^{3}$ & 42.4 & 40.5 & 41.5 & 40.8 \\
\hline $\mathrm{NE}_{\mathrm{L}},{ }^{2} \mathrm{Mcal} / \mathrm{kg}$ & 1.54 & 1.56 & 1.56 & 1.58 \\
\hline $\mathrm{Ca}$ & 1.01 & 0.89 & 1.05 & 1.00 \\
\hline $\mathrm{P}$ & 0.33 & 0.32 & 0.35 & 0.35 \\
\hline $\mathrm{Mg}$ & 0.35 & 0.33 & 0.35 & 0.34 \\
\hline $\mathrm{K}$ & 1.00 & 0.89 & 0.93 & 0.97 \\
\hline $\mathrm{S}$ & 0.19 & 0.21 & 0.22 & 0.26 \\
\hline \multicolumn{5}{|c|}{ PSPS DM basis, $\mathrm{mm}^{4}$} \\
\hline$>19.0$ & 15.3 & 14.9 & 16.2 & 17.3 \\
\hline $19.0-8.0$ & 21.7 & 21.5 & 21.8 & 21.4 \\
\hline $8.0-1.18$ & 38.3 & 36.4 & 34.9 & 28.4 \\
\hline$<1.18$ & 24.7 & 27.2 & 27.1 & 32.0 \\
\hline
\end{tabular}

${ }^{1} \mathrm{SBM}=$ soybean meal; HPDDG $=$ high protein dried distillers grains with solubles; $\mathrm{CM}=$ canola meal; DDGS = dried distillers grains with solubles. Dietary treatments consisted of 4 different protein sources (SBM, HPDDG, CM, and DDGS) intended to supply equal amounts of protein (approximately $38 \%$ of the total dietary protein) from the respective supplemental protein sources.

${ }^{2}$ Estimated values from NRC (2001).

${ }^{3} \mathrm{NFC}=100-$ ether extract $-\mathrm{CP}-\mathrm{NDF}-$ ash.

${ }^{4}$ PSPS $=$ Penn State Particle Separator.

(Somacount 500, Bentley Instruments; method 975.16; AOAC, 2002). An extra sample was taken one day during the last week of each period for milk nitrogen fractions. Samples were mixed by gentle inversion and analyzed for total milk protein (method 991.20; AOAC, 2002), nonprotein nitrogen (method 991.21; AOAC, 2002), and noncasein nitrogen (method 998.05; AOAC, 2002), with true protein (method 991.23; AOAC, 2002) and casein nitrogen (method 998.07; AOAC, 2002) calculated by difference.

Body condition scores on a scale of 1 to 5 (Wildman et al., 1982) and BW were recorded approximately $3 \mathrm{~h}$ after feeding for 3 consecutive days at the start of the experiment and at the end of each period. Blood was collected at the end of each period from the coccygeal artery and subcutaneous abdominal vein into vacuum tubes containing heparin (Becton Dickinson and Co., Franklin Lakes, NJ). Plasma was obtained by centrifuging at $500 \times g$ and stored at $-20^{\circ} \mathrm{C}$ until analyzed for
AA via HPLC (model 1100, Agilent Technologies Inc., Palo Alto, CA) with a PCX 5200 postcolumn derivatizer (Pickering Laboratories Inc., Mountain View, CA) as described by Mondina et al. (1972), Pickering (1989), and Grunau and Swiader (1992). Extraction efficiencies of AA by the mammary gland were calculated based on the following equation: arteriovenous difference of AA $(\mathrm{g} / \mathrm{L}) \times 100 /$ concentration $(\mathrm{g} / \mathrm{L})$ in plasma of coccygeal artery.

Samples of rumen fluid were obtained via an esophageal tube fitted with a suction strainer on 2 consecutive days at the end of each period approximately $3 \mathrm{~h}$ after feeding. The first $150 \mathrm{~mL}$ was discarded to minimize saliva contamination and then approximately $250 \mathrm{~mL}$ of rumen fluid was collected. A $10-\mathrm{mL}$ aliquot was mixed with $2 \mathrm{~mL}$ of $25 \%$ (wt/vol) metaphosphoric acid and frozen at $-20^{\circ} \mathrm{C}$ until centrifuged at 20,000 $\times g$ and analyzed for concentrations of ammonia-N (Weatherburn, 1976) and VFA. Concentrations of VFA were 
Table 3. Composition of forages and concentrate mixes for treatment $\operatorname{diets}^{1}$

\begin{tabular}{|c|c|c|c|c|c|c|c|c|c|c|c|}
\hline Item, $\%$ of DM unless noted & \multicolumn{7}{|c|}{ Ingredient } & \multicolumn{4}{|c|}{ Concentrate mix } \\
\hline DM, $\%$ & 88.6 & 47.4 & 88.0 & 90.4 & 92.4 & 89.9 & 86.2 & 87.7 & 88.2 & 88.5 & 88.6 \\
\hline $\mathrm{EE}^{2}$ & 1.41 & 2.50 & 1.49 & 3.42 & 3.77 & 9.57 & 2.30 & 4.72 & 4.20 & 4.17 & 3.40 \\
\hline $\mathrm{ADF}$ & 32.1 & 21.2 & 5.55 & 10.1 & 16.4 & 5.18 & 2.37 & 3.44 & 4.21 & 6.64 & 5.18 \\
\hline $\mathrm{NDF}$ & 42.6 & 40.1 & 9.08 & 28.7 & 22.0 & 26.1 & 9.66 & 10.4 & 18.6 & 13.8 & 18.8 \\
\hline $\mathrm{Ca}$ & 1.59 & 0.20 & 0.56 & 0.01 & 1.44 & 0.04 & & & & & \\
\hline $\mathrm{Mg}$ & 0.38 & 0.25 & 0.30 & 0.11 & 0.59 & 0.37 & & & & & \\
\hline $\mathrm{P}$ & 0.27 & 0.22 & 0.71 & 0.43 & 1.16 & 0.89 & & & & & \\
\hline K & 1.80 & 0.60 & 2.46 & 0.39 & 1.38 & 1.18 & & & & & \\
\hline S & 0.23 & 0.11 & 0.42 & 0.86 & 0.84 & 1.02 & & & & & \\
\hline
\end{tabular}

${ }^{1} \mathrm{SBM}=$ soybean meal; HPDDG = high protein dried distillers grains with solubles; $\mathrm{CM}=$ canola meal; DDGS $=$ dried distillers grains with solubles. Dietary treatments consisted of 4 different protein sources (SBM, HPDDG, CM, and DDGS) intended to supply equal amounts of protein (approximately 38\% of the total dietary protein) from the respective supplemental protein sources.

${ }^{2} \mathrm{EE}=$ ether extract.

${ }^{3} \mathrm{NFC}=100-\mathrm{EE}-\mathrm{CP}-\mathrm{NDF}-$ ash.

measured using a 6890 gas chromatograph (HewlettPackard, Anondale, PA) equipped with a column (0.25 mm i.d. $\times 15$ m; Nukol, 17926 to 01C, Supelco Inc., Bellenfonte, PA). The split ratio in the injector port $\left(250^{\circ} \mathrm{C}\right)$ was $100: 1$ with a flow of $1.3 \mathrm{~mL} / \mathrm{min}$ of He. Column and detector temperatures were maintained at 130 and $225^{\circ} \mathrm{C}$, respectively.

Means of DMI, milk yield, and milk composition were used in statistical analysis. Analysis of variance was conducted using the MIXED procedure of SAS (SAS Institute Inc., Cary, NC): Y = treatment + square + period + cow (square), where cow (square) was the random variable. The treatment $\times$ square and treatment $\times$ period interactions were tested and removed because they were not significant. Least squares means of the treatments were calculated and separation was determined using PDIFF. Significance was declared at $P<0.05$ and tendencies noted at $P<0.10$.

\section{RESULTS AND DISCUSSION}

\section{Nutrient Composition}

All diets (Table 2) were slightly lower in CP (15.3\%) than the anticipated $16 \% \mathrm{CP}$, which was acceptable because with a protein evaluation study such as this it was important that diets not contain excess protein. Analyses of ingredients (Table 3) indicated where these minor discrepancies occurred. The alfalfa hay contained less protein than preliminary analyses indicated. Also, the CP in the HPDDG (44.6\%) was lower than values used in formulation (46\%). The ether extract content of the DDGS used was on the low end of the fat content of typical DDGS, which is why the DDGS diet contained slightly less ether extract (4.1\%) than the other diets $(4.6 \%)$.

\section{Particle Size}

Particle size of diets was determined on all treatment diets using the Penn State Particle Separator during wk 3 and 4 of each period (Table 2; Kononoff et al., 2003). Each sieve was dried to determine the percent on a DM basis, as recommended by Kononoff et al. (2003). The amount of DM retained on the top sieve of the particle separator was between 14.9 and $17.3 \%$. The middle sieve was low in all diets, ranging from 21.4 to $21.8 \%$. The screen and pan had from 28.4 to $38.3 \%$ on the screen and 24.7 to $32.0 \%$ in the pan. All diets were similar in particle size distribution and within normal expected ranges.

\section{DMI, Milk Production, and BW}

Dry matter intake $(24.8 \mathrm{~kg} / \mathrm{d})$, milk production $(31.8$ $\mathrm{kg} / \mathrm{d}), \operatorname{ECM}(34.7 \mathrm{~kg} / \mathrm{d})$, and feed efficiency (1.44) were similar for all diets (Table 4). This was similar to results by Liu et al. (2000), where there was no change in milk production when feeding DDGS versus a blend of SBM, DDGS, and fishmeal. However, Nichols et al. (1998) and Anderson et al. (2006) observed an increase in milk production when feeding DDGS versus SBMbased control diets. But, those studies did not balance the fat content of all diets; thus, part of their response might have been attributable to the increased fat content of the DDGS diets. Hubbard et al. (2009) observed increased milk production when HPDDG was fed in place of SBM. Piepenbrink et al. (1998), Brito and 
Table 4. Dry matter intake, milk yield, milk composition, and BW (LSM) from lactating dairy cattle fed treatment $\operatorname{diets}^{1}$

\begin{tabular}{|c|c|c|c|c|c|c|}
\hline \multirow[b]{2}{*}{ Item } & \multicolumn{4}{|c|}{ Diet $^{2}$} & \multirow[b]{2}{*}{ SEM } & \multirow[b]{2}{*}{$P$-value } \\
\hline & SBM & HPDDG & $\mathrm{CM}$ & DDGS & & \\
\hline DMI, kg/d & 24.1 & 24.6 & 25.2 & 23.6 & 0.85 & 0.45 \\
\hline Milk yield, $\mathrm{kg} / \mathrm{d}$ & 31.7 & 31.2 & 31.7 & 32.7 & 1.59 & 0.63 \\
\hline $\mathrm{ECM}^{3} \mathrm{~kg} / \mathrm{d}$ & 35.1 & 34.8 & 34.6 & 34.3 & 1.74 & 0.95 \\
\hline ECM/DMI & 1.48 & 1.45 & 1.38 & 1.46 & 0.09 & 0.64 \\
\hline $\mathrm{N}$ efficiency ${ }^{4}$ & 0.299 & 0.300 & 0.272 & 0.296 & 0.02 & 0.29 \\
\hline Fat, $\%$ & $4.21^{\mathrm{a}}$ & $4.21^{\mathrm{a}}$ & $4.07^{\mathrm{ab}}$ & $3.78^{\mathrm{b}}$ & 0.16 & 0.02 \\
\hline Fat, kg/d & 1.33 & 1.31 & 1.28 & 1.24 & 0.08 & 0.53 \\
\hline Protein, \% & $3.33^{\mathrm{a}}$ & $3.36^{\mathrm{a}}$ & $3.33^{\mathrm{a}}$ & $3.23^{\mathrm{b}}$ & 0.09 & 0.08 \\
\hline Protein, $\mathrm{kg} / \mathrm{d}$ & 1.04 & 1.05 & 1.05 & 1.05 & 0.05 & 0.99 \\
\hline Lactose, \% & 4.71 & 4.73 & 4.72 & 4.75 & 0.06 & 0.58 \\
\hline Lactose, $\mathrm{kg} / \mathrm{d}$ & 1.50 & 1.48 & 1.50 & 1.55 & 0.09 & 0.65 \\
\hline MUN, mg/dL & 9.85 & 9.21 & 9.83 & 9.81 & 0.45 & 0.50 \\
\hline $\mathrm{SCC}, 10^{3}$ cells $/ \mathrm{mL}$ & 535 & 359 & 359 & 324 & 211 & 0.21 \\
\hline $\mathrm{BW}, \mathrm{kg}$ & 683 & 681 & 686 & 684 & 17.9 & 0.56 \\
\hline BW, $\mathrm{kg}$ of change/d & -0.65 & -0.93 & -1.04 & -0.88 & 0.14 & 0.11 \\
\hline $\mathrm{BCS}^{5}$ & 3.45 & 3.47 & 3.47 & 3.47 & 0.08 & 0.87 \\
\hline BCS, change/d & 0.0004 & 0.07 & 0.03 & 0.06 & 0.03 & 0.35 \\
\hline \multicolumn{7}{|c|}{$\overline{\mathrm{a}, \mathrm{b}}$ Values within rows with different superscripts differ $(P<0.05)$. } \\
\hline \multicolumn{7}{|c|}{${ }^{1}$ Least squares means. } \\
\hline \multicolumn{7}{|c|}{$\begin{array}{l}{ }^{2} \mathrm{SBM}=\text { soybean meal; HPDDG }=\text { high protein dried distillers grains with solubles; } \mathrm{CM}=\text { canola mea } \\
\text { DDGS = dried distillers grains with solubles. Dietary treatments consisted of } 4 \text { different protein sources (SBM } \\
\text { HPDDG, CM, and DDGS) intended to supply equal amounts of protein (approximately } 38 \% \text { of the total di } \\
\text { etary protein) from the respective supplemental protein sources. }\end{array}$} \\
\hline
\end{tabular}

Broderick (2007), and Sanchez and Claypool (1983) all observed similar milk production when feeding CM in place of SBM; however, Brito and Broderick (2007) and Sanchez and Claypool (1983) reported an increase in DMI when CM was fed in place of SBM. Mulrooney et al. (2009) observed similar production when DDGS or CM was fed and slightly higher production with blends of the 2 protein supplements. Body weights $(684 \mathrm{~kg}$; Table 4), BW changes, BCS (3.47), and BCS changes were similar across treatments. No treatment effects on these parameters were expected.

\section{Milk Composition}

Milk fat percentage (Table 4) was higher with the SBM and HPDDG diets than with the DDGS diet, whereas with the CM diet it was similar to all other diets. The lower fat content observed when DDGS was fed with adequate forage fiber as in this experiment was somewhat unexpected because Kalscheur (2005) observed that milk fat content was lower only in diets supplemented with wet or dried distillers grains with solubles diets that contained less than $50 \%$ forage and $22 \%$ forage NDF. The similar milk fat percentage with the SBM and CM diets agreed with others (Sanchez and Claypool, 1983; Piepenbrink et al., 1998; Brito and
Broderick, 2007; Mulrooney et al., 2009). When Hubbard et al. (2009) fed HPDDG in place of SBM, milk fat yields were higher because of higher milk production coupled with numerically higher fat test.

Milk protein content was higher in the SBM, HPDDG, and CM diets than in the DDGS diet, but protein yield was similar across all diets because of the numerically higher milk yield when DDGS was fed. Milk protein content is seldom affected by feeding distillers grains with solubles unless protein is limiting in the diet (Schingoethe et al., 2009), which may have occurred in this study because the diets contained marginal amounts of protein, especially RDP (NRC, 2001). Then the Lys limitation in DDGS may cause a slight decrease in milk protein content (Nichols et al., 1998; Kleinschmit et al., 2006). Considering the limitations of calculating estimated balances of RDP (NRC, 2001), all 4 diets were low but positive for estimated RDP balance $(359,104,247$, and $133 \mathrm{~g} / \mathrm{d}$ for the SBM, HPDDG, CM, and DDGS diets, respectively), with the 2 distillers product diets having the lowest RDP (Table 2 ) and RDP balance. Estimated balances for RUP ( -8 , 208,9 , and $87 \mathrm{~g} / \mathrm{d}$, respectively) are even less reliable because accurate data are not available on HPDDG or on some of the other dietary ingredients. Thus, the above-estimated RDP and RUP balances illustrate that 
Table 5. Protein fractionations of milk protein (LSM) from lactating dairy cattle fed treatment diets

\begin{tabular}{lcccccc}
\hline & \multicolumn{3}{c}{ Diet $^{1}$} & & \\
\cline { 2 - 5 } Item & SBM & HPDDG & CM & DDGS & SEM & $P$-value \\
\hline Total CP, ${ }^{2} \%$ & $3.36^{\mathrm{b}}$ & $3.43^{\mathrm{a}}$ & $3.33^{\mathrm{b}}$ & $3.29^{\mathrm{b}}$ & 0.09 & 0.01 \\
NPN, ${ }^{\mathrm{b}} \%$ & 0.20 & 0.19 & 0.19 & 0.19 & 0.01 & 0.25 \\
True protein, ${ }^{2} \%$ & $3.17^{\mathrm{b}}$ & $3.28^{\mathrm{a}}$ & $3.15^{\mathrm{b}}$ & $3.09^{\mathrm{b}}$ & 0.09 & 0.01 \\
Casein N, ${ }^{2} \%$ & $2.65^{\mathrm{b}}$ & $2.77^{\mathrm{a}}$ & $2.67^{\mathrm{ab}}$ & $2.57^{\mathrm{b}}$ & 0.08 & 0.01 \\
\% of total protein & & & & & & \\
True & 93.9 & 94.4 & 93.3 & 94.1 & 0.29 & 0.17 \\
Casein & 78.9 & 79.2 & 79.7 & 78.3 & 0.81 & 0.41 \\
\hline
\end{tabular}

${ }^{\mathrm{a}, \mathrm{b}}$ Values within rows with different superscripts differ $(P<0.05)$.

${ }^{1} \mathrm{SBM}=$ soybean meal; HPDDG $=$ high protein dried distillers grains with solubles; $\mathrm{CM}=$ canola meal; DDGS $=$ dried distillers grains with solubles. Dietary treatments consisted of 4 different protein sources (SBM, HPDDG, CM, and DDGS) intended to supply equal amounts of protein (approximately $38 \%$ of the total dietary protein) from the respective supplemental protein sources.

${ }^{2} \mathrm{~N} \times 6.38$.

using such simulated calculations based on currently available NRC (2001) formulations can be inaccurate and possibly of minimal value. Sanchez and Claypool (1983) and Brito and Broderick (2007) observed no change in milk protein percentages when feeding CM, whereas Piepenbrink et al. (1998) observed an increase in protein percentage when CM was fed and Mulrooney et al. (2009) observed similar milk protein percentages when fed DDGS, CM, or their blends. Milk urea nitrogen concentrations were similar across all treatments but were low, likely because of the intended low $\mathrm{CP}$ in the diets.

\section{Milk Protein Fractions}

Milk protein fractions (Table 5) were analyzed to determine whether the AA profile of the protein source fed affected milk protein. Total and true protein contents were highest $(P<0.05)$ with the HPDDG diets at 3.43 and $3.28 \%$, respectively. When fed the SBM, CM, and DDGS diets, total and true protein contents were similar $(P>0.05)$. The percentage of casein in the milk was highest with HPDDG and lowest with the SBM and DDGS diets $(P<0.05)$. With $\mathrm{CM}$, casein content was in the middle, which was similar $(P>0.05)$ to the content with all other diets. This showed that the increase in true protein could be partly attributable to an increase in casein.

\section{Rumen Parameters}

The total VFA concentrations and proportions of various VFA (Table 6) were not affected by the dietary treatment $(P>0.07)$. This is in contrast with Nichols et al. (1998), where the addition of DDGS to the diet resulted in a decrease in total VFA. Piepenbrink et al. (1998) observed decreased total VFA concentra- tions when CM was included in the diet. The proportions of acetate $(68.3 \%)$, propionate $(18.2 \%)$, butyrate $(9.99 \%)$, and isovalerate $(1.37 \%)$ were not affected by treatments, which indicated a similar fermentation pattern among diets and was consistent with other studies (Nichols et al., 1998; Anderson et al., 2006; Brito and Broderick, 2007). There was a trend $(P>0.07)$ for slightly lower concentrations of isobutyrate and valerate with HPDDG and CM, but these changes did not necessarily reflect the branched-chain AA composition of the protein supplements (NRC, 2001), were not likely biologically significant, and did not relate to RDP balance or AA composition of the protein supplements. Ammonia concentrations in the rumen $(3.9 \mathrm{mg} / \mathrm{dL})$ were unaffected by treatments but were relatively low, as expected, because diets were low in protein (Roffler and Satter, 1975).

\section{Blood AA}

Total essential AA concentrations in arterial plasma (Table 7) tended to be lower when fed CM and concentrations in venous plasma were lower $(P<0.05)$ with CM (Table 8), as also reported by Piepenbrink and Schingoethe (1998). Leucine and Phe concentrations were higher $(P<0.05)$ with HPDDG than with SBM and CM and tended $(P>0.05)$ to be higher with DDGS. There was a tendency for an increase in venous concentrations of Met when HPDDG was fed as compared with SBM, which was somewhat related to the higher Met concentration in corn protein. There was no effect of treatment on the venous or arterial concentrations of Lys in this experiment. As expected based on the AA composition of the protein supplements (NRC, 2001), Met concentration in plasma tended to be lowest with the SBM diet whereas Lys tended to be lowest with the 2 distillers product diets, which again reflected 
Table 6. Ruminal VFA and ammonia (LSM) from lactating dairy cattle fed treatment diets ${ }^{1}$

\begin{tabular}{lcccccc}
\hline & \multicolumn{7}{c}{ Diet } & & \\
\cline { 2 - 4 } Measurement & SBM & HPDDG & CM & DDGS & SEM & $P$-value \\
\hline VFA, \% & & & & & \\
Acetate (A) & 67.8 & 68.9 & 69.0 & 67.4 & 0.77 & 0.33 \\
Propionate (P) & 18.3 & 17.8 & 18.0 & 18.6 & 0.57 & 0.69 \\
Isobutyrate & $1.07^{\mathrm{a}}$ & $0.90^{\mathrm{b}}$ & $0.92^{\mathrm{b}}$ & $0.95^{\mathrm{ab}}$ & 0.06 & 0.07 \\
Butyrate & 10.2 & 9.68 & 9.58 & 10.5 & 0.36 & 0.17 \\
Isovalerate & 1.44 & 1.43 & 1.34 & 1.28 & 0.09 & 0.42 \\
Valerate & $1.20^{\mathrm{ab}}$ & $1.16^{\mathrm{b}}$ & $1.18^{\mathrm{b}}$ & $1.33^{\mathrm{a}}$ & 0.05 & 0.08 \\
A:P & 3.74 & 3.95 & 3.87 & 3.66 & 0.16 & 0.52 \\
Total, $\mathrm{m} M / \mathrm{L}$ & 49.7 & 52.6 & 54.8 & 43.2 & 6.35 & 0.48 \\
Ammonia, mg/dL & 4.50 & 3.93 & 4.49 & 2.52 & 0.83 & 0.18 \\
\hline
\end{tabular}

${ }^{\mathrm{a}, \mathrm{b}}$ Values within rows with different superscripts differ $(P<0.05)$.

${ }^{1} \mathrm{SBM}=$ soybean meal; HPDDG = high protein dried distillers grains with solubles; $\mathrm{CM}=$ canola meal; DDGS $=$ dried distillers grains with solubles. Dietary treatments consisted of 4 different protein sources (SBM, HPDDG, CM, and DDGS) intended to supply equal amounts of protein (approximately $38 \%$ of the total dietary protein) from the respective supplemental protein sources.

AA composition of the protein supplements. Arteriovenous differences (Table 9) were essentially similar for all diets.

Transfer efficiency and uptake to output ratios consider only AA relative to secretion as milk protein (Kleinschmit et al., 2007). Extraction efficiency, however, may be the ideal method for evaluating AA requirements because it takes into account the entire essential AA needs of the mammary gland and includes AA extracted for all needs such as protein synthesis and catabolism (Schingoethe, 1996; Nichols et al., 1998; Kleinschmit et al., 2007). Also, the possibility of inaccuracies when estimating mammary blood flow is not a concern because mammary blood flow is not a part of the calculations for extraction efficiency, whereas it is included in the other 2 calculation methods. In this

Table 7. Amino acid concentrations in plasma from the coccygeal artery (LSM) in lactating dairy cows fed treatment diets $^{1}$

\begin{tabular}{|c|c|c|c|c|c|c|}
\hline \multirow[b]{2}{*}{ Item } & \multicolumn{4}{|c|}{ Diet } & \multirow[b]{2}{*}{ SEM } & \multirow[b]{2}{*}{$P$-value } \\
\hline & SBM & HPDDG & $\mathrm{CM}$ & DDGS & & \\
\hline \multicolumn{7}{|l|}{ Essential AA, $\mu \mathrm{mol} / \mathrm{dL}$} \\
\hline Arg & 8.73 & 7.56 & 8.17 & 8.95 & 0.66 & 0.41 \\
\hline His & $4.87^{\mathrm{a}}$ & $5.31^{\mathrm{a}}$ & $4.05^{\mathrm{b}}$ & $5.09^{\mathrm{a}}$ & 0.40 & 0.03 \\
\hline Ile & 11.90 & 10.69 & 9.48 & 10.65 & 0.86 & 0.13 \\
\hline Leu & $15.37^{\mathrm{bc}}$ & $18.54^{\mathrm{a}}$ & $12.73^{\mathrm{c}}$ & $16.49^{\mathrm{ab}}$ & 1.25 & 0.01 \\
\hline Lys & 8.01 & 7.50 & 7.73 & 7.49 & 0.55 & 0.82 \\
\hline Met & 1.83 & 2.18 & 2.02 & 2.01 & 0.15 & 0.34 \\
\hline Phe & $3.65^{\mathrm{b}}$ & $4.40^{\mathrm{a}}$ & $3.54^{\mathrm{b}}$ & $4.03^{\mathrm{ab}}$ & 0.19 & 0.01 \\
\hline Thr & 8.28 & 9.41 & 8.63 & 7.79 & 0.66 & 0.23 \\
\hline Trp & 3.01 & 3.16 & 2.70 & 2.05 & 0.26 & 0.58 \\
\hline Val & $25.68^{\mathrm{a}}$ & $24.20^{\mathrm{a}}$ & $20.19^{\mathrm{b}}$ & $23.52^{\mathrm{ab}}$ & 1.68 & 0.03 \\
\hline Total essential AA & $91.27^{\mathrm{a}}$ & $92.98^{\mathrm{a}}$ & $79.24^{\mathrm{b}}$ & $88.89^{\mathrm{ab}}$ & 4.83 & 0.08 \\
\hline \multicolumn{7}{|c|}{ Nonessential AA, $\mu \mathrm{mol} / \mathrm{dL}$} \\
\hline Ala & 20.87 & 23.01 & 22.06 & 21.34 & 1.26 & 0.54 \\
\hline Asp & 3.18 & 2.87 & 3.19 & 3.26 & 0.29 & 0.22 \\
\hline Asn & 0.73 & 0.86 & 0.70 & 0.80 & 0.07 & 0.22 \\
\hline Glu & 24.24 & 27.59 & 25.75 & 26.63 & 1.25 & 0.11 \\
\hline Gln & $4.29^{\mathrm{b}}$ & $4.63^{\mathrm{b}}$ & $5.27^{\mathrm{a}}$ & $4.72^{\mathrm{ab}}$ & 0.22 & 0.01 \\
\hline Gly & 27.04 & 27.07 & 26.75 & 25.70 & 1.85 & 0.92 \\
\hline Pro & $6.26^{\mathrm{b}}$ & $8.67^{\mathrm{a}}$ & $5.66^{\mathrm{b}}$ & $6.11^{\mathrm{b}}$ & 0.53 & 0.01 \\
\hline Ser & 8.64 & 9.21 & 7.95 & 8.43 & 0.53 & 0.35 \\
\hline Tyr & $4.26^{\mathrm{b}}$ & $5.90^{\mathrm{a}}$ & $4.31^{\mathrm{b}}$ & $4.98^{\mathrm{ab}}$ & 0.35 & 0.01 \\
\hline Total nonessential AA & 105.53 & 117.72 & 107.59 & 108.05 & 4.49 & 0.19 \\
\hline
\end{tabular}

${ }^{a-c}$ Values within rows with different superscripts differ $(P<0.05)$.

${ }^{1} \mathrm{SBM}=$ soybean meal; HPDDG $=$ high protein dried distillers grains with solubles; $\mathrm{CM}=$ canola meal; DDGS $=$ dried distillers grains with solubles. Dietary treatments consisted of 4 different protein sources (SBM, HPDDG, CM, and DDGS) intended to supply equal amounts of protein (approximately $38 \%$ of the total dietary protein) from the respective supplemental protein sources. 
Table 8. Amino acid concentrations $(\mu \mathrm{mol} / \mathrm{dL})$ in plasma from the subcutaneous abdominal vein (LSM) in lactating dairy cows fed treatment $\operatorname{diets}^{1}$

\begin{tabular}{|c|c|c|c|c|c|c|}
\hline \multirow[b]{2}{*}{ Item } & \multicolumn{4}{|c|}{ Diet } & \multirow[b]{2}{*}{ SEM } & \multirow[b]{2}{*}{$P$-value } \\
\hline & SBM & HPDDG & $\mathrm{CM}$ & DDGS & & \\
\hline \multicolumn{7}{|l|}{ Essential AA, $\mu \mathrm{mol} / \mathrm{dL}$} \\
\hline Arg & 5.62 & 4.65 & 5.67 & 4.85 & 0.65 & 0.52 \\
\hline His & $3.57^{\mathrm{a}}$ & $4.06^{\mathrm{a}}$ & $2.74^{\mathrm{b}}$ & $3.77^{\mathrm{a}}$ & 0.38 & 0.01 \\
\hline Ile & $7.89^{\mathrm{a}}$ & $6.56^{\mathrm{ab}}$ & $4.93^{\mathrm{b}}$ & $6.39^{\mathrm{ab}}$ & 0.84 & 0.08 \\
\hline Leu & $9.33^{\mathrm{a}}$ & $11.80^{\mathrm{a}}$ & $6.30^{\mathrm{b}}$ & $9.87^{\mathrm{a}}$ & 1.13 & 0.01 \\
\hline Lys & 3.27 & 3.22 & 2.96 & 2.78 & 0.39 & 0.69 \\
\hline Met & $0.67^{\mathrm{b}}$ & $1.03^{\mathrm{a}}$ & $0.87^{\mathrm{ab}}$ & $0.76^{\mathrm{ab}}$ & 0.11 & 0.07 \\
\hline Phe & $1.70^{\mathrm{b}}$ & $2.44^{\mathrm{a}}$ & $1.66^{\mathrm{b}}$ & $1.85^{\mathrm{b}}$ & 0.16 & 0.01 \\
\hline Thr & 5.77 & 6.30 & 5.66 & 5.66 & 0.62 & 0.79 \\
\hline Trp & 2.69 & 2.61 & 2.25 & 2.93 & 0.24 & 0.34 \\
\hline Val & $20.48^{\mathrm{a}}$ & $19.87^{\mathrm{a}}$ & $14.64^{\mathrm{b}}$ & $17.86^{\mathrm{ab}}$ & 1.60 & 0.01 \\
\hline Total essential AA & $61.02^{\mathrm{a}}$ & $61.54^{\mathrm{a}}$ & $47.71^{\mathrm{b}}$ & $56.48^{\mathrm{ab}}$ & 4.07 & 0.02 \\
\hline \multicolumn{7}{|c|}{ Nonessential AA, $\mu \mathrm{mol} / \mathrm{dL}$} \\
\hline Ala & 17.29 & 19.17 & 17.44 & 17.49 & 1.28 & 0.55 \\
\hline Asp & $1.95^{\mathrm{b}}$ & $2.63^{\mathrm{a}}$ & $1.96^{\mathrm{b}}$ & $1.93^{\mathrm{b}}$ & 0.22 & 0.04 \\
\hline Asn & $0.41^{\mathrm{b}}$ & $0.59^{\mathrm{a}}$ & $0.43^{\mathrm{b}}$ & $0.50^{\mathrm{ab}}$ & 0.06 & 0.05 \\
\hline Glu & $17.54^{\mathrm{b}}$ & $21.85^{\mathrm{a}}$ & $19.39^{\mathrm{ab}}$ & $18.40^{\mathrm{ab}}$ & 1.28 & 0.04 \\
\hline Gln & $1.89^{\mathrm{b}}$ & $2.11^{\mathrm{ab}}$ & $2.35^{\mathrm{a}}$ & $2.06^{\mathrm{ab}}$ & 0.13 & 0.06 \\
\hline Gly & 24.32 & 26.87 & 25.57 & 25.07 & 1.82 & 0.69 \\
\hline Pro & $4.39^{\mathrm{b}}$ & $6.56^{\mathrm{a}}$ & $3.87^{\mathrm{b}}$ & $4.50^{\mathrm{b}}$ & 0.44 & 0.01 \\
\hline Ser & 5.91 & 6.40 & 4.89 & 5.41 & 0.53 & 0.12 \\
\hline Tyr & $2.38^{\mathrm{b}}$ & $4.09^{\mathrm{a}}$ & $2.26^{\mathrm{b}}$ & $2.78^{\mathrm{b}}$ & 0.32 & 0.01 \\
\hline Total nonessential AA & $81.97^{\mathrm{b}}$ & $96.30^{\mathrm{a}}$ & $83.13^{\mathrm{b}}$ & $85.51^{\mathrm{ab}}$ & 4.13 & 0.06 \\
\hline
\end{tabular}

${ }^{\mathrm{a}, \mathrm{b}}$ Values within rows with different superscripts differ $(P<0.05)$.

${ }^{1} \mathrm{SBM}=$ soybean meal; HPDDG $=$ high protein dried distillers grains with solubles; $\mathrm{CM}=$ canola meal; DDGS $=$ dried distillers grains with solubles. Dietary treatments consisted of 4 different protein sources (SBM, HPDDG, CM, and DDGS) intended to supply equal amounts of protein (approximately $38 \%$ of the total dietary protein) from the respective supplemental protein sources.

Table 9. Arteriovenous differences in AA plasma (LSM) from lactating dairy cows fed treatment diets ${ }^{1}$

\begin{tabular}{|c|c|c|c|c|c|c|}
\hline \multirow[b]{2}{*}{ Item } & \multicolumn{4}{|c|}{ Diet } & \multirow[b]{2}{*}{ SEM } & \multirow[b]{2}{*}{$P$-value } \\
\hline & SBM & HPDDG & $\mathrm{CM}$ & DDGS & & \\
\hline \multicolumn{7}{|l|}{ Essential AA, $\mu \mathrm{mol} / \mathrm{dL}$} \\
\hline Arg & 3.14 & 2.89 & 2.70 & 3.90 & 0.56 & 0.42 \\
\hline His & 1.29 & 1.25 & 1.31 & 1.32 & 0.09 & 0.92 \\
\hline Ile & 3.81 & 4.16 & 4.80 & 4.27 & 0.52 & 0.59 \\
\hline Leu & 6.02 & 6.86 & 6.38 & 6.62 & 0.32 & 0.27 \\
\hline Lys & 4.71 & 4.29 & 4.77 & 4.73 & 0.24 & 0.24 \\
\hline Met & 1.18 & 1.14 & 1.17 & 1.25 & 0.10 & 0.87 \\
\hline Phe & 1.95 & 1.96 & 1.84 & 2.19 & 0.14 & 0.29 \\
\hline Thr & $2.50^{\mathrm{ab}}$ & $3.04^{\mathrm{a}}$ & $3.05^{\mathrm{a}}$ & $2.32^{\mathrm{b}}$ & 0.26 & 0.09 \\
\hline Trp & 0.39 & 0.76 & 0.50 & 0.32 & 0.16 & 0.22 \\
\hline Val & 5.18 & 5.48 & 5.50 & 5.65 & 0.32 & 0.74 \\
\hline Total essential AA & 29.99 & 31.63 & 31.93 & 32.43 & 1.67 & 0.72 \\
\hline \multicolumn{7}{|c|}{ Nonessential AA, $\mu \mathrm{mol} / \mathrm{dL}$} \\
\hline Ala & 3.89 & 3.90 & 3.58 & 3.78 & 0.58 & 0.53 \\
\hline Asp & 1.24 & 1.24 & 1.22 & 1.34 & 0.13 & 0.89 \\
\hline Asn & 0.32 & 0.25 & 0.29 & 0.31 & 0.05 & 0.83 \\
\hline Glu & 6.71 & 5.74 & 6.25 & 7.33 & 0.60 & 0.13 \\
\hline Gln & 2.44 & 2.46 & 2.93 & 2.68 & 0.16 & 0.11 \\
\hline Gly & $2.61^{\mathrm{a}}$ & $1.13^{\mathrm{b}}$ & $1.47^{\mathrm{b}}$ & $1.08^{\mathrm{b}}$ & 0.42 & 0.06 \\
\hline Pro & 1.87 & 2.12 & 1.79 & 1.62 & 0.25 & 0.51 \\
\hline Ser & 2.65 & 2.83 & 2.09 & 3.09 & 0.36 & 0.72 \\
\hline Tyr & 1.88 & 1.81 & 2.06 & 2.20 & 0.15 & 0.23 \\
\hline Total nonessential AA & 23.85 & 21.07 & 23.83 & 23.00 & 1.52 & 0.40 \\
\hline
\end{tabular}

${ }^{a, b}$ Values within rows with different superscripts differ $(P<0.05)$.

${ }^{1} \mathrm{SBM}=$ soybean meal; HPDDG $=$ high protein dried distillers grains with solubles; $\mathrm{CM}=$ canola meal; DDGS $=$ dried distillers grains with solubles. Dietary treatments consisted of 4 different protein sources (SBM, HPDDG, CM, and DDGS) intended to supply equal amounts of protein (approximately $38 \%$ of the total dietary protein) from the respective supplemental protein sources. 
Table 10. Extraction efficiencies ${ }^{1}(\%)$ of essential AA (EAA) from blood to mammary gland (LSM) for lactating dairy cows fed treatment $\operatorname{diets}^{2,3}$

\begin{tabular}{|c|c|c|c|c|c|c|}
\hline \multirow[b]{2}{*}{ EAA } & \multicolumn{4}{|c|}{ Diet } & \multirow[b]{2}{*}{ SEM } & \multirow[b]{2}{*}{$P$-value } \\
\hline & SBM & HPDDG & $\mathrm{CM}$ & DDGS & & \\
\hline $\operatorname{Arg}$ & $36.3(6)$ & $39.2(4)$ & $32.6(9)$ & $43.2(5)$ & 5.25 & 0.52 \\
\hline His & $27.2^{\mathrm{b}}(9)$ & $26.2^{\mathrm{b}}(9)$ & $37.4^{\mathrm{a}}(7)$ & $26.5^{\mathrm{b}}(9)$ & 3.76 & 0.05 \\
\hline Ile & $35.6(7)$ & 39.1 (5) & $45.8(6)$ & $26.5(9)$ & 3.54 & 0.17 \\
\hline Leu & $41.6^{\mathrm{b}}(5)$ & $37.7^{\mathrm{b}}(6)$ & $51.1^{\mathrm{a}}(4)$ & $41.8^{\mathrm{b}}(6)$ & 3.08 & 0.01 \\
\hline Lys & $60.1(2)$ & 58.8 (1) & $63.3(1)$ & $63.6(1)$ & 2.81 & 0.49 \\
\hline Met & $64.1(1)$ & $54.0(2)$ & $58.5(2)$ & $63.2(2)$ & 3.99 & 0.16 \\
\hline Phe & $54.0^{\mathrm{a}}(3)$ & $44.2^{\mathrm{b}}(3)$ & $52.2^{\mathrm{a}}(3)$ & $54.1^{\mathrm{a}}(3)$ & 3.04 & 0.03 \\
\hline Thr & $31.1(8)$ & $32.3(7)$ & $36.6(8)$ & $30.6(8)$ & 3.17 & 0.51 \\
\hline Trp & $45.7^{\mathrm{a}}(4)$ & $31.5^{\mathrm{b}}(8)$ & $49.4^{\mathrm{a}}(5)$ & $45.4^{\mathrm{a}}(4)$ & 3.26 & 0.01 \\
\hline Val & $21.4^{\mathrm{b}}(10)$ & $22.6^{\mathrm{b}}(10)$ & $27.6^{\mathrm{a}}(10)$ & $25.3^{\mathrm{ab}}(10)$ & 2.00 & 0.03 \\
\hline Tyr & $44.5^{\mathrm{a}}[5]$ & $30.7^{\mathrm{b}}[9]^{\prime}$ & $47.8^{\mathrm{a}}[5]$ & $44.2^{\mathrm{a}}[5]$ & 3.10 & 0.04 \\
\hline Total EAA & $33.6^{\mathrm{b}}$ & $34.5^{\mathrm{b}}$ & $39.9^{\mathrm{a}}$ & $37.0^{\mathrm{ab}}$ & 1.81 & 0.04 \\
\hline
\end{tabular}

${ }^{a, b}$ Values within rows with different superscripts differ $(P<0.05)$.

${ }^{1}$ Extraction efficiencies $=$ arteriovenous difference of AA $(\mathrm{g} / \mathrm{L}) \times 100 /$ concentration $(\mathrm{g} / \mathrm{L})$ of AA in plasma of coccygeal artery.

${ }^{2} \mathrm{SBM}=$ soybean meal; HPDDG = high protein dried distillers grains with solubles; $\mathrm{CM}=$ canola meal; DDGS $=$ dried distillers grains with solubles. Dietary treatments consisted of 4 different protein sources (SBM, HPDDG, CM, and DDGS) intended to supply equal amounts of protein (approximately $38 \%$ of the total dietary protein) from the respective supplemental protein sources.

${ }^{3}$ Numbers in parentheses indicate the apparent order of limiting AA. Numbers in brackets are for Tyr if it were considered an essential AA.

study, extraction efficiency (Table 10) indicated that Met was the first limiting AA by the mammary gland with SBM, whereas Lys was first limiting with the other diets. Phenylalanine was third limiting with all diets but was less limiting $(P<0.05)$ with the HPDDG diet than with the other diets. Likewise, Leu, Trp, and Val were less limiting with the HPDDG diet. If Tyr were considered to be an essential AA, as it is in most animal tissues (Schingoethe, 1996), it was less limiting with the HPDDG diet than with the other diets. Thus, whereas the first limiting AA were essentially of the same degree of limitation with all protein supplements evaluated, there were some indications of improved AA balance when fed HPDDG.

\section{CONCLUSIONS}

The recently available HPDDG is a high protein, lower fat product of ethanol processing available to the feed industry. When fed to lactating cows as the source of supplemental protein, HPDDG was equal to SBM, CM, and DDGS. Cows fed the HPDDG diet produced the most casein in the milk protein and thus may have provided the most desirable AA profile for casein production. Extraction efficiency of AA from blood by the mammary gland indicated that Lys was the first limiting AA for HPDDG, CM, and DDGS diets, whereas Met was first limiting for the SBM diet.

\section{ACKNOWLEDGMENTS}

The authors gratefully acknowledge the farm crew at the South Dakota State University Dairy Research Unit (Brookings) for care of the cows and assistance with data collection. The authors also express appreciation for partial funding by Dakota Gold Research Association (Sioux Falls, SD) and to Poet Nutrition (Sioux Falls, SD) for supplying the HPDDG and DDGS used in this research.

\section{REFERENCES}

Anderson, J. L., D. J. Schingoethe, K. F. Kalscheur, and A. R. Hippen. 2006. Evaluation of dried and wet distillers grains included at two concentrations in diets of lactating dairy cows. J. Dairy Sci. 89:3133-3142.

AOAC. 2002. Official Methods of Analysis. 18th ed. Association of Official Analytical Chemists, Gaithersburg, MD.

Brito, A. F., and G. A. Broderick. 2007. Effects of different protein supplements on milk production and nutrient utilization in lactating dairy cows. J. Dairy Sci. 90:1816-1827.

Chaney, A. L., and E. P. Marbach. 1962. Modified reagents for determination of urea and ammonia. Clin. Chem. 8:130-132.

Grunau, J. A., and J. M. Swiader. 1992. Chromatography of 99 amino acids and other ninhydrin-reactive compounds in the Pickering lithium gradient system. J. Chromatogr. A 594:165-171.

Hubbard, K. J., P. J. Kononoff, A. M. Gehman, J. M. Kelzer, K. Karges, and M. L. Gibson. 2009. Short communication: The effect of feeding high protein distillers dried grains on milk production of Holstein cows. J. Dairy Sci. 92:2911-2914.

Kalscheur, K. F. 2005. Impact of feeding distillers grains on milk fat, protein, and yield. Proc. Distillers Grains Technology Council, 9th Annual Symposium, Louisville, KY. Distillers Grains Technology Council, Louisville, KY. 
Kleinschmit, D. H., D. J. Schingoethe, A. R. Hippen, and K. F. Kalscheur. 2007. Dried distillers grains plus solubles with corn silage or alfalfa hay as the primary forage source in dairy cow diets. J. Dairy Sci. 90:5587-5599.

Kleinschmit, D. H., D. J. Schingoethe, K. F. Kalscheur, and A. R. Hippen. 2006. Evaluation of various sources of corn distillers dried grains plus solubles for lactating dairy cattle. J. Dairy Sci. 89:4784-4794.

Kononoff, P. J., A. J. Heinrichs, and D. R. Buckmaster. 2003 Modification of the Penn State forage and total mixed ration particle separator and effects of moisture content on its measurements. J. Dairy Sci. 86:1858-1863.

Liu, C., D. J. Schingoethe, and G. A. Stegeman. 2000. Corn distillers grains versus a blend of protein supplements with or without ruminally protected amino acids for lactating cows. J. Dairy Sci. 83:2075-2084

Mondina, A., G. Bongiovanni, S. Fumero, and L. Rossi. 1972. An improved method of plasma deproteination with sulphosalicylic acid for determining amino acids and related compounds. J. Chromatogr. A 74:255-263.

Mulrooney, C. N., D. J. Schingoethe, K. F. Kalscheur, and A. R. Hippen. 2009. Canola meal replacing distillers grains with solubles for lactating dairy cows. J. Dairy Sci. 92:5669-5676.

NRC. 2001. Nutrient Requirements of Dairy Cattle. 7 th rev. ed. Natl. Acad. Sci., Washington, DC.

Nichols, J. R., D. J. Schingoethe, H. A. Maiga, M. J. Brouk, and M. S. Piepenbrink. 1998. Evaluation of corn distillers grains and ruminally protected lysine and methionine for lactating dairy cows. J. Dairy Sci. 81:482-491.

Pickering, M. 1989. Ion-exchange chromatography of free amino acids. LC GC 7:484-490.

Piepenbrink, M. S., and D. J. Schingoethe. 1998. Ruminal degradation, amino acid composition, and estimated intestinal digestibility of four protein supplements. J. Dairy Sci. 81:454-461.
Piepenbrink, M. S., D. J. Schingoethe, M. J. Brouk, and G. A Stegeman. 1998. Systems to evaluate the protein quality of diets fed to lactating cows. J. Dairy Sci. 81:1046-1061.

Robertson, J. B., and P. J. Van Soest. 1981. The detergent system of analysis and its application to human foods. Pages 123-158 in The Analysis of Dietary Fiber in Food. W. P. T. James and O. Theander, ed. Marcel Dekker Inc., New York, NY.

Robinson, P. H., K. Karges, and M. L. Gibson. 2008. Nutritional evaluation of four co-product feedstuffs from the motor fuel ethanol distillation industry in the Midwestern USA. Anim. Feed Sci. Technol. 146:345-352.

Roffler, R. E., and L. D. Satter. 1975. Relationship between ruminal ammonia and nonprotein nitrogen utilization by ruminants. I. Development of a model for predicting nonprotein nitrogen utilization by cattle. J. Dairy Sci. 58:1880-1888.

Sanchez, J. M., and D. W. Claypool. 1983. Canola meal as a protein supplement in dairy rations. J. Dairy Sci. 66:80-85.

Schingoethe, D. J. 1996. Balancing the amino acid needs of the dairy cow. Anim. Feed Sci. Technol. 60:153-160.

Schingoethe, D. J., K. F. Kalscheur, A. R. Hippen, and A. D. Garcia 2009. Invited review: The use of distillers products in dairy cattle diets. J. Dairy Sci. 92:5802-5813.

Van Soest, P. J., J. B. Robertson, and B. A. Lewis. 1991. Methods for dietary fiber, neutral detergent fiber, and nonstarch polysaccharides in relation to animal nutrition. J. Dairy Sci. 74:3583-3597.

Weatherburn, M. W. 1976. Phenol-hypochlorite reaction for determinations of ammonia. Anal. Chem. 39:971-974.

Wildman, E. E., G. M. Jones, P. E. Wagner, R. L. Boman, H. F. Troutt Jr., and T. N. Lesch. 1982. A dairy cow body condition scoring system and its relationship to standard production characteristics. J. Dairy Sci. 65:495-501. 